\title{
As perspectivas da Literatura e da História em Luanda, cidade e literatura
}

\author{
Rejane Vecchia da Rocha e Silva \\ (Universidade de São Paulo)
}

m seu recente livro Luanda, cidade e literatura (São Paulo: Editora Unesp; Luanda: Nzila, 2008, 237 páginas), a professora Tania Macêdo percorre as ruas de Luanda conciliando dois campos fundamentais do saber: o literário e o histórico. Valendo-se de uma leitura que privilegia as imbricações permanentes entre a realidade simbólica da ficção e a realidade material da História, a autora constrói uma cuidadosa análise a respeito das condições de vida dos angolanos na cidade de Luanda. Para tanto, parte do olhar de seus escritores que descrevem a cidade e seus conflitos, desvendando ao longo das últimas décadas também na literatura as tensões dialéticas próprias de um país que atravessou o longo período do sistema colonial português, a guerra de independência, a guerra civil e o momento presente em que as condições econômicas de um mundo tomado pelo mercado financeiro e suas crises ocupam o cenário político-econômico mundial e portanto, inevitavelmente, Angola.

Assim, refletir acerca da inserção de Angola nas políticas econômicas mundiais, ao longo de sua História, vislumbrando um horizonte para além das fronteiras do país, bem como, em oposição, estabelecer um recorte, através da capital do país, Luanda, pelo qual se torna possível perceber como internamente as políticas externas vêm interferindo no crescimento e na organização deste espaço, são aspectos fundamentais que permeiam este trabalho da autora. Sobretudo por meio da perspectiva da crítica literária, opera o resgate da emergência de temas políticos nos conteúdos do campo ficcional. Elabora, dessa forma, uma via de mão dupla em que as tensões dialéticas que se estampam nas narrativas ficcionais abordadas, próprias de um cenário social convulsionado pela ocupação colonial, pela pilhagem, pelo empobrecimento econômico, pela corrupção, balizam o seu trabalho. 
O livro que se inicia por meio da descrição física da cidade, aos poucos se abre para a dimensão social luandense:

À vista dessa parte da cidade [a "Baixa", parte da cidade que fica próxima ao mar], não há como deixar de pensar que grande parte da história da capital angolana foi alheia a seu povo, na medida em que as marcas do período colonial ainda hoje presentes em suas ruas e edifícios apontam para a história do colonizador, de sua ocupação e exploração no território angolano. (p. 12)

Ou ainda

O olhar do visitante de Luanda pode, no entanto, fugindo das marcas deixadas pelos colonizadores, procurar uma outra Angola e a encontrará, por exemplo, nos edifícios públicos de construção pós-independência do país - ocorrida a 11 de novembro de 1975 - como o palácio do Congresso ou nas praças públicas, como o Largo $1^{\circ}$ de Maio e do Kinaxixi. (p. 12)

\section{Mais adiante}

Mas há uma outra realidade de Luanda: a que se revela a partir dos mercados livres que levam o nome de programas da televisão brasileira como Roque Santeiro e Os trapalhões, ou ainda em suas ruas congestionadas e com pavimentação em estado crítico, com um número enorme de crianças de rua, ao lado de uma grande frota de automóveis de luxo, de casas gradeadas e guardadas por cães e empresas privadas de segurança, de bairros clandestinos que crescem assustadoramente do dia para a noite, da ruína dos edifícios históricos ou da destruição do patrimônio urbano. (pp. 12-13)

Luanda, cidade e literatura, portanto, organiza-se a partir de uma leitura de sua cartografia que é histórica, política e social, para então voltar-se ao tema central proposto pela autora, ou seja, o surgimento de Luanda como o espaço privilegiado das narrativas ficcionais de muitos de seus escritores, que ao longo dos últimos cinqüenta anos seguiram em direção a uma "paulatina reafricanização de Luanda", procurando não só o sentido de Nação, "mas também de uma especificidade nacional, ou seja, da "angolanidade" (p. 16).

Tania Macêdo parte, assim, por meio da literatura, em busca das muitas personagens que figuram na narrativa ficcional angolana e que traduzem os 
caminhos da resistência, da sobrevivência e do confronto à marginalidade imposta - no passado e no presente. O livro divide-se em cinco partes: "Percorrendo algumas ruas da teoria", "A cidade africana", "A cidade portuguesa no além-mar", "A cidade colonizada" e "A cidade reafricanizada".

Nesse percurso proposto, a apresentação inicial do projeto teórico-metodológico para o desenvolvimento da análise literária indica não só a postura crítica da professora em termos de seu trabalho com o texto literário, mas também, inevitavelmente, a sua própria adesão política junto àqueles que simbolizaram e simbolizam a resistência aos sistemas político-econômicos de opressão. No entanto, essa adesão que se pode dizer, também, afetiva, não contraria o rigor de sua leitura, pois que a autora cuidadosamente trabalha para que as especificidades do campo ficcional não sejam submetidas à realidade da vida, estabelecendo de forma muito atenta as imbricações sempre possíveis e pertinentes entre literatura e sociedade.

Nesse sentido, retoma a história do continente africano anterior à chegada dos europeus, estabelecendo, dessa forma, as possibilidades de abordagem e ruptura de paradigmas referentes ao continente construídos ao longo dos séculos. Isso ocorre, por exemplo, em relação à crença do surgimento das cidades africanas a partir do processo colonial. A pesquisa é minuciosa em busca de uma conceituação adequada, de dados e documentos de como eram as cidades africanas, sua organização e suas dinâmicas de funcionamento antes da chegada do europeu. Nessa esteira, propõe, também, uma reflexão em torno dos discursos oficiais metropolitanos que forjavam uma realidade exclusivamente de barbárie quando se reportavam ao continente africano e suas populações. Vale notar que este trabalho da professora Tania Macêdo também convoca os leitores a algumas reflexões acerca de como na contemporaneidade o continente africano é visto e quais são os estereótipos historicamente construídos que ainda permanecem no imaginário social de muitos países, inclusive do Brasil.

Nesse contexto, a análise desenvolvida pela autora remete o leitor à questão da oralidade predominante nas lógicas culturais em África fortalecendo esses "habitus" culturais que intensificam e fortalecem as relações sociais de seus grupos locais no que diz respeito à transmissão dos conhecimentos, da história, dos ensinamentos e, portanto, da importância dos mais velhos, do espaço da memória e "do poder da palavra". Enfatiza a importância das relações de afeto que estão pressupostas em tais dinâmicas sociais, bem como a 
importância da transmissão dos valores. O passo seguinte é analisar como tais processos podem e/ou poderiam ser refeitos através da escrita ficcional de modo a encenar na literatura outras formas de apreensão da vida que se distanciem das práticas ocidentalizadas e eurocêntricas. Trabalha com o conceito de oratura e discute esse trânsito intranqüilo, diríamos, em que

as manifestações culturais tradicionais que chegaram até nós vêm filtradas por séculos de presença européia no território angolano (ainda que ela não tenha sido abrangente) e, portanto, considerá-las a "pura expressão" popular ou a expressão de uma "idade do ouro" seria, no mínimo, escamotear a história. (p. 54)

Analisa as mudanças que ao longo dos tempos foram acontecendo na cidade de Luanda a partir da chegada de Paulo Dias de Novais e a construção de um imaginário social aderido às perspectivas políticas e ideológicas dos colonizadores, sobretudo no que diz respeito ao tráfico de escravos, "grande riqueza do "Reino de Angola"' (p. 72). Resultado da ocupação colonial é um mundo cindido entre centros de poder e periferias marginais ou os "bairros indígenas" ou a "cidade do colonizado". Essa cisão, sem dúvida, revela-se na geografia dos espaços e em Luanda não será diferente como aponta a pesquisadora. E resultado dessa divisão é a própria tensão dialética entre centro urbano e periferia, divisão esta desenhada na geografia de Luanda. De um lado a opulência, do outro, a carência, contrastes que, segundo a autora, servirão de impulso à organização de núcleos de resistência dentro dessas periferias e de onde também a Luanda da escrita ficcional se organiza.

A partir da escolha de textos produzidos nesse contexto, dos debates e embates advindos das necessidades e problemas vividos pelas populações locais, e seguindo uma determinada ordem cronológica, é cuidadosamente analisado o repertório literário produzido ao longo dos últimos cinqüenta anos evidenciando a partir de uma cidade reafricanizada, por exemplo, os musseques e seus habitantes, sejam as mulheres, as crianças, os homens.

A autora procura ainda abarcar um número significativo de escritores angolanos, seus textos e, na interlocução pretendida e muito bem realizada a partir de Luanda entre Política e História e Literatura, torna possível ao leitor debruçar-se sobre uma dada realidade ficcional e compartilhar de experiências de vida que têm muito a nos ensinar. 